https://helda.helsinki.fi

\title{
The global bases of inequality regimes : the case of international nurse recruitment
}

\section{Näre, Lena}

2021-06-08

Näre , L \& Silva , T C 2021, ' The global bases of inequality regimes : the case of international nurse recruitment ' , Equality, Diversity and Inclusion, vol. 40 , no. 5 , pp. 510-524 . https://doi.org/10.1108/EDI-02-2020-0039

http://hdl.handle.net/10138/332257

https://doi.org/10.1108/EDI-02-2020-0039

cc_by_nc

acceptedVersion

Downloaded from Helda, University of Helsinki institutional repository.

This is an electronic reprint of the original article.

This reprint may differ from the original in pagination and typographic detail.

Please cite the original version. 

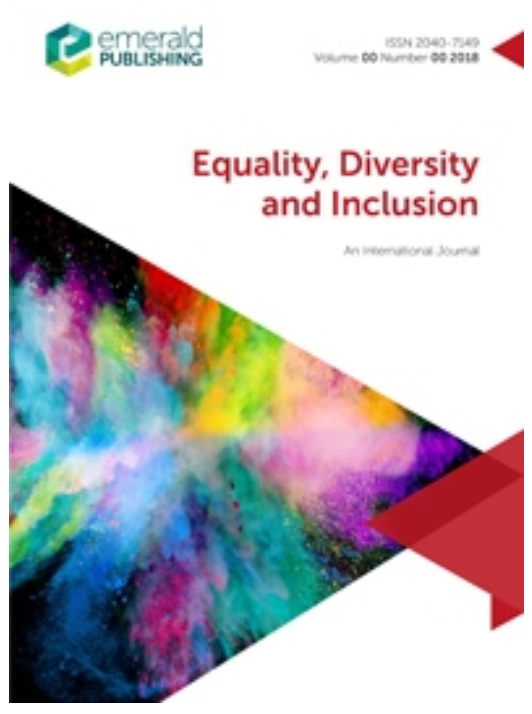

The global bases of inequality regimes: The case of international nurse recruitment

\begin{tabular}{|r|l|}
\hline Journal: & Equality, diversity and inclusion: An international journal \\
\hline Manuscript ID & EDI-02-2020-0039.R3 \\
\hline Manuscript Type: & Original Article \\
\hline Keywords: & $\begin{array}{l}\text { Inequality regimes, Nurse recruitment, Discrimination, Gender, Global } \\
\text { Care Chains, Global Nurse Care Chains }\end{array}$ \\
\hline
\end{tabular}

\section{SCHOLARONE \\ Manuscripts}




\title{
The global bases of inequality regimes: The case of international nurse recruitment
}

\begin{abstract}
Purpose:

The purpose of this article is to critically examine Joan Acker's notion of inequality regimes by applying it to the case of global nurse care chains (GNCCs). The article examines the organisational practices of GNCCs and how inequality barriers are practiced and legitimised.
\end{abstract}

Research design: The article is based on qualitative interviews with different institutional representatives involved in Filipino nurse recruitment to Finland $(\mathrm{N}=25)$, recruited Filipino nurses $(\mathrm{N}=20)$, and Filipino nurses working in Finland $(\mathrm{N}=9)$.

Findings: The article demonstrates different organisational practices through which inequality regimes are created and sustained. These include the racialised construction of the Philippines as situated in the global periphery and functioning as a resource of labour for the global core and the Filipino nurse as innately more caring. The inequalities are legitimised through deskilling in which the nurses' command of Finnish language is a key form of justification. Filipino nurses' precarious legal status renders them compliant workers from an organisational perspective and vulnerable workers who fear to claim their rights as workers.

Practical and social implications: By discussing barriers to inequality, the article illustrates how inequalities in diverse workplaces and the undervaluing of nurse work could be addressed. 
Originality: The article uniquely applies Acker's inequality regimes to the study of GNCCs. It argues that the concept of inequality regimes would benefit from developing it towards a global context.

Key words: inequality regimes, global care chains, nurse recruitment, global nurse care chains, discrimination, gender

\section{Introduction}

The on-going global corona pandemic illustrates the predicament between the vital need of nurse work, the health risks associated in the work and the continuous undervaluing of nursing work in terms of recognition and fair compensation (Davies, 1995; WHO, 2020;). This comes as no surprise to researchers who, since 1970s, have analysed women's discrimination in organisations and the devaluing of female labour (Acker, 1990; 2006a; 2006b; Kanter, 1977). Women's work is often not perceived as work at all (Duffy, 2011; Mohanty, 1997).

One indication of the continuous undervaluing of nursing is its global commodification shaped by neoliberal economic restructuring processes and austerity measures (Wrede, 2012). Nordic and European welfare states have decentralised, privatised, contracted out and cut down care provisions that were formerly provided by the state (Meagher $\&$ Szebehely 2013), enabling private companies the opportunity to capitalise and profit from nursing work. In migration 'sending countries' of the Global South, such as the Philippines, neoliberal economic restructuring has reduced the state provision of social care and education and increased individuals' burden to pay for health care and education in private markets (Rodriguez, 2010). 
Global care chains conceptualise commodified care labour (Hochschild, 2000; Parreñas, 2001; Yeates, 2009; 2011; 2012). Global care chains (GCCs) refer to a series of 'personal links between people across the globe based on the paid and unpaid work of caring' (Hochschild, 2000, p. 131). Yeates $(2009 ; 2011)$ expands GCCs that focus on personal households as the locus of care work to include diverse occupational, sectorial, organisational, and institutional settings involved in the globalisation of care work, including professional care labour. Yeates (2009, p. 75-122) defines Global Nurse Care Chains (GNCCs) as consisting of nursing institutions, the nurses themselves, nursing or educational institutions and multi-level actors involved in the recruitment and governance of these chains. The diverse actors that are involved in GNCCs include state authorities who implement immigration legislation and nursing licensing, corporate and other actors involved in the recruitment, training and placement of nurses and the nurses themselves (Cleland Silva, 2018; Vaittinen, 2014).

The transnationalization of care (Yeates, 2011) depends on various organisational practices through which the migrant nurse workforce is produced by private and public sector actors such as corporate recruitment agencies, workplace institutions and the state. Yet, GNCCs are seldom analysed from an explicitly organisational perspective. Thus, the aim of this article is to apply theories of inequalities practiced in organisations, namely Joan Acker's (2006a; 2006b) concept of inequality regimes, to the analysis of GNCCs.

Joan Acker (2006a, p. 443) defines inequality regimes as 'loosely interrelated practices, processes, actions, and meanings that result in and maintain class, gender, and racial inequalities in particular organisations'. In this article, we refer to the complex multiactor-led process of international recruitment and placement of health care personnel 
from the Philippines to Finland as the 'particular organisation' rather than the elderly care facility or hospital in which the recruited nurses work. Thus, the organisation we are studying is inherently transnational connecting Finland and the Philippines.

In applying Acker's concept of inequality regimes to the global scale, we also expand the boundaries of Acker's theory. The article proposes the notion of global bases of inequality regimes as a conceptual tool to analyse the complex dynamics between local, organisational inequalities and global hierarchies of power (Metcalfe and Woodhams, 2012). The notion of global coloniality is useful here. Global coloniality refers to the 'model of power relations that came into existence as a consequence of the Western imperial expansion but did not end with the official end of colonialism' (Tlostanova and Mignolo, 2012, p. 7).

The article illustrates the global bases of inequality regimes by analysing the case of Filipino nurse recruitment to Finland. This research concentrates on processes and practices of recruitment and placement within GNCCs, the practices through which work is organised, and how inequalities, within healthcare organisations, are produced and maintained. In what follows, we first discuss our analytical framework, then the context of our research, our data and methods, followed by the findings and conclusions.

\section{Towards a global inequality regime perspective}

Within inequality regimes, Acker distinguishes between six barriers to equality: 1) the bases of inequality; 2) the shape and degree of inequality; 3) the organising processes; 4) 
the invisibility of inequality; 5) the legitimacy of inequality and 6) control and compliance. These barriers serve as an analytical organisational approach to local, ongoing practical activities of organising work in which complex inequalities are reproduced (Acker, 2006a, p. 442). While Acker (2006a, p. 454) mentions the recruitment of illegal migrant workers as a form of control under the sixth barrier, the global dimension is otherwise not fully developed in the original formulation of inequality regimes.

Our article applies the six barriers to equality to the global context by analysing transnational organisational practices of recruitment and placement in Finnish health care organisations. The first barrier, the bases of inequality, is considered in our case to be the global hierarchy in which the Philippines is perceived as a poor country of the global south and, as such, a resource of workforce for the global north (Parreñas, 2001). Regarding the second barrier, the shape and degree of inequality, health care organisations have traditionally been hierarchical within various occupational levels (Davies, 1995). Nurses represent a high proportion of employees, and yet, this dominance does not equate to significant organisational power (Carter and Silva, 2010). The global dimension increases inequalities in health care organisations due to complex practices of deskilling (Duffy, 2011) and discrimination deriving from the precarious legal status of migrant workers. The first and second barrier are closely intertwined in that the global recruitment of nurses can enhance internal hierarchies amongst nurses within a health care organisation and in the nursing profession more widely. This is the case when the credentials of nurses from the global south are not recognised, and they are hired into lower graded nursing jobs. 
The third barrier, organising processes, directs the focus to various practices of recruitment in the Philippines but also the placement and organisation practices within the workplaces in Finland and how these create new kinds of inequalities. The fourth barrier, the invisibility of inequality, is apparent in the case of Filipino nurse recruitment that is commonly described as a win-win-win situation for all the actors involved (the nurse, the organisation and the nation-state). This effectively hides the global inequalities that materialise through the organisational practices. The fifth barrier identifies the legitimacy of organisational actors (re)enforcing inequalities within the global care chains, and the last barrier, control and compliance, is discussed by examining how organisational practices systematically produce authority amongst selected private and public actors, but also compliance within the organisational day-to-day operations amongst the nurses.

\section{Organising Global Nurse Care Chains from the Philippines to Finland}

Since the 1950s, the Philippines have been training nurses and sending them abroad (Choy, 2003), and they are now the single largest country of origin of international nurses (OECD, 2015). The Philippine's government has facilitated nurse migration through long-standing economic strategies, despite the Philippines' weak domestic health care system and lack of resources (Masselink et al., 2010).

Nursing is just one occupation in the pool of global workers from the Philippines. Filipinos around the world are employed as domestic and care workers, seamen, engineers, cooks, clerical and agricultural workers and so forth. Global labour brokerage is the main neoliberal strategy of the Philippines nation-state to generate 'profit' from the 
remittances migrants send back and, in this way, to service the country's indebtedness (Barber, 2000; Rodriguez, 2010). In 2019, the effects of this governmental strategy are 2.2 million Overseas Filipino Workers (OFW) and estimated remittances of PhP 211.9 billion (Philippines Statistics Authority, 2019). Women have dominated the general labour exportation from the Philippines over the last decades and mainly occupy work positions within the care industry (Ball, 2004).

Finland is relatively a new destination country for international health care personnel. Since 2006, Finnish governments have been supportive of labour migration (Näre, 2013). The latest statistics indicate that there are over 384,000 people with a migration history living in Finland, corresponding to 7 percent of the population (Statistics Finland, 2019). However, this figure says very little of the reality at the local level. The country's capital, Helsinki, is a much more diverse space with 15.5 percent of its population having a migration history in 2018 (City of Helsinki, 2019).

These changing demographics also reflect a change in the local labour markets. Like the other Nordic welfare states ${ }^{1}$, Finland has traditionally recruited health care professionals mainly nationally and internationally within the Nordic region, where cultural ties are comparatively close and all the countries have extensive welfare states (Isaksen, 2010; Wrede et al., 2008). However, recent political and economic practices within the global healthcare industry have created a competitive market amongst countries that equates to big business (Buchan et al., 2003). Parallel reforms within Nordic welfare states have shifted employer's responsibilities from permanent, stable, unionized labour to more flexible and cheaper labour (Wrede and Näre, 2013; van Riemsdijk, 2010). This socio- 
political context favours private companies who profit from providing the demanded workforce of the local labour markets.

International nurse recruitment is a complex process because both labour migration and the nursing profession are regulated in Finland. Nursing is a protected profession as educating and licensing nurses is a practice controlled by The National Supervisory Authority for Welfare and Health (Valvira): a government agency operating under the Ministry of Social Affairs and Health. In Finland, labour migration is means-tested, which requires employers to first establish if there is available labour force in Finland or the EU/EEA before applying for a residence permit of a non-EU citizen. Other requirements for employment-based residence permits include a full-time work contract adhering to collective agreements.

Decisions on employment-based work permits are thus given by the Finnish Immigration Office based on partial decisions made by the Centre for Economic Development, Transport and the Environment. As nursing is a labour sector that is not liberated from means testing, Finnish HR companies need to interview unemployed nurses in Finland before they can proceed with external recruitment. The HR companies need a partner in the Philippines that interviews potential nurses. In the case we studied, the partner also organised Finnish language training before the nurses were selected. The training was costly, and a disproportionate number of aspiring nurses paid for Finnish language training in comparison to the small number of actual places for recruited nurses (Näre, 2012). To illustrate the various actors and organisations involved in the international nurse recruitment from the Philippines to Finland please see Figure 1. 
Figure 1: The key actors in the global organisation of nurse recruitment from the Philippines to Finland. The perspective of those marked in italics have been included in this study.

\section{Figure 1 here}

The actors represented in blue boxes are those who are actively involved in the organisation of recruitment and placement, while the bodies listed in the transparent boxes are organisations that regulate the wider institutional and social context in which the recruitment takes place. Although we were unable to include the perspective of organisations in the Philippines in our study design, we know from existing research that the Philippine Overseas Employment Agency (POEA) has played a key role in developing the country's migration industry since the 1970s. It is a government agency that processes workers' contracts and implements pre-deployment checks as well as licenses, regulates and monitors private recruitment agencies (Asis, 2006). Also, the nursing educational sector has grown rapidly as hundreds of nursing colleges educate nurses to the domestic and global labour markets (Lorenzo et al., 2007).

In addition to recruiting nurses, private Finnish companies have recruited approximately 100 chefs, 300 cleaners and 100 domestic workers from the Philippines. Yet, only the nurse recruitment gained vast media attention and is considered the pioneering case for a model, which is perceived by some institutional stakeholders as the answer to Finland's worsening dependency ratio (Näre and Nordberg, 2016).

\section{Data and Methods}


Our research design is multi-level in that our data consist of interviews with representatives of organisations who are stakeholders in the international nurse recruitment, representing the meso-level as well as micro-level interviews with Filipino nurses. We find that this multi-level analysis is needed to understand how inequality regimes are not only limited within particular organisations, but affected by various organisations, that are national, local and global in nature. This is a useful strategy to unpack inequalities in organisations that have a global dimension, such as the GNCCs. This way we have been able to combine data on the micro-level experiences of workers but also on the narratives of representatives of meso-level organisations.

The data were collected over 26 months between November 2009 and December 2012, with purposive sampling in relation to recruitment of nurses from outside of the European Union. The data consist of 25 individual interviews done separately by the authors with different institutional stakeholders, including trade union representatives $(\mathrm{N}=3)$; civil servants working for different ministries and the City of Helsinki $(\mathrm{N}=8)$; representatives of three different recruitment companies, one of which has been involved in the active recruitment of Filipino nurses $(\mathrm{N}=6)$; representatives of care facilities employing the Filipino nurses at elderly care $(\mathrm{N}=8)$; and 29 interviews with Filipino nurses who have been either directly recruited to Finland in 2008-2012 (N=20) or who have migrated to Finland through marriage or who have a migration background and have subsequently been recruited to the healthcare sector $(\mathrm{N}=9)$. As the recruitment and placement of the Filipino nurses was considered new at the time, the organisational representatives interviewed were approached by the researchers through snowball sampling and attending public events organised by the recruiters and other Finnish representatives 
claiming to recruit nurses from the Philippines. The Filipino nurses were contacted through Filipino associations in Finland and a Finnish teacher involved in the Filipino community in Finland.

There were approximately 100 Filipino nurses who were actively recruited by Finnish organisations during the time of data collection, and the recruitment has continued since the first group arrived in 2008 (Vartiainen et al., 2018). In relation to these relatively small numbers of Filipino nurses working in Finland, our interview sample is sufficient. Also, a saturation point was achieved as no new themes emerged in the interviews.

The interview questions concerned the organisation and its role in the recruitment and placement of nurses, the actual recruitment and placement practices and the wider social significance and motivation of the recruitment and placement. The Filipino nurses were asked to narrate openly their family, educational and social background in the Philippines, their work experience, reasons for migrating, and their experiences of the recruitment as well as the work, migration legislation and education and language training in Finland.

\begin{abstract}
All the interviews were transcribed verbatim. The data analysis was conducted through the authors individually and together by a close-reading of the interview transcripts and analysing the transcripts thematically using open 'codes' to be critical of our potential prior assumptions of the data (Bryman and Burgess, 1994). We developed the codes abductively by reorganising data through familiarising ourselves with data, line-by-line coding, then categorising the codes and building larger themes. Going back and forth between data and theoretical literature was central to the abductive process (Dubois and
\end{abstract}


Gadde, 2002). In table I, we open the coding, categorising and thematising process, focusing specifically on barriers and inequality regimes.

\section{Table I here}

Due to the small number of Filipino nurses recruited to Finland, the anonymity of the research participants is a pressing matter. To protect the anonymity of the participants, we do not use pseudonyms, and we refrain from identifying the workplaces in which the interviewees worked.

\section{The global bases of inequality regimes}

GNCCs do not emerge out of nowhere but are created and crafted through organisational practices that are both local and transnational. As illustrated by Yeates (2009), these chains are organised through practices by various private and public organisational actors that work in tandem or separately in similar or different temporal and geographical contexts. As the healthcare industry remains highly gendered and ethnicised in terms of organisational hierarchical structures (Kingma, 2006; Yeates, 2009), these structures are appropriated and reproduced within the chains. The interviews reveal global hierarchies of power that underpin the GNCCs. These constructions legitimise the organisational inequality barriers in the recruitment and placement practices during various stages of the process.

In the Finnish organisational context, the Philippines is constructed by the representatives from the recruitment organisations as a quasi-endless source for good quality human 
capital. In these narratives, a racialised stereotype of the Filipino nurse as feminised, innately caring and thus different to the more professional Finnish nurse is created. Filipino nurses are portrayed with a 'keenness' to care, in contrast to 'colder' more professional Finnish nurses. A representative from a private education centre reflects on the difference between the Finnish and Filipino nurse as follows:

They [Filipino nurses] understand that the elderly are very important. They are keen about other people's feelings and they love the family.... It is the different culture [in the Philippines]. There [in the Philippines] they take care of their older people at homes. In Finland, this is very uncommon at present. A representative from a private HR company involved in nurse recruitment from the Philippines constructs the GNCCs and its commodified products as easy to purchase in the Philippines. The representative also notes how the nurses and their abilities are valued in other countries within the global trade:

We know that we are not going to have to search too hard for the nurses there [in the Philippines] and they [nurses] have this ability to sell in other countries very quickly.

In these narratives, Filipino nurses are commodified as products bought and sold on global markets. They are racialised as keen, caring and family-oriented people. The local organisations are central, and because of the valued educational system in the Philippines, the nurses can be commodified globally.

The Philippines as a source for workforces is constructed in another private recruitment representative's reflections of the nurses' cultural attributes, nursing qualifications and English level proficiency in the Philippines as well as the institutionalised educational system which derives from the United States and is set up to export nurses abroad: 
They value education and the quality of nursing education is good. It was basically planned by the Americans, so it is no wonder that there are so many Filipino nurses in the United States. The quality of the degree and of course the culturally bound politeness and, when we think of the elderly people here [Finland], they [Filipinos] have a natural respect for the elderly which we could learn from actually. And, also, that they speak English and they have studied in English. (...) We have, in a way, a common language then in Finland so we don't need interpreters.

This quote illustrates the underpinning logic of the nurse recruitment based on global coloniality. It is the Western education system that guarantees the quality of the Filipino nurses' skills. The American education system confirms that the nurses are not only skilled because of their 'natural' aptitude for care. Moreover, here English language proficiency is used as an argument in favour of recruiting from the Philippines and as a basis of commonality, but as discussed below, language is also used as a basis of difference and inequality in workplace practices.

In the recruitment process, registered nurses from the Philippines are selected to work as practical nurses in Finland because the recruitment organisation's Finnish clients requested these specific human resources. A private representative hired as a Finnish language trainer within the placement process recalls the objective of the recruiting and client organisations, and reiterates that the Philippines was chosen because of the country's history of exporting nurses to 'everywhere' but especially to the 'West':

[Recruiters] had the customer and they talked together and [the customer] had needs about the new practical nurses and they decided how it is possible to get people from other countries. And, after quite a lot of research, they decided the country should be the Philippines because they had experience about exporting the nurses out to Canada, everywhere.

In the constructions by the representatives in the interviews, Finland, as a country and a culture, is depicted as 'better' than other destination countries for Filipino nurses in terms 
of treatment and reception of the recruited nurses. 'Here', or Finland, entails work practices of commonality (e.g., English language and Western model of patient care and medicine), but also fair work practices according to which the non-Finnish nurse is treated the same as the Finnish nurse by law. In an interview with a representative whose organisation works on behalf of private business employers, the representative compares Finland to Arab countries as a better country for Filipino nurses. Reproducing racist stereotypes and hierarchies embedded into global coloniality, the representative states that "I think for them [Filipino nurses], it is better to work in Finland than some Arab country".

\section{The organisational practices of GNCCs legitimising global inequalities}

The recruitment of the nurses in the Philippines was outsourced to a Filipino partner company. They also were responsible for the Finnish language training to which the Filipino nurses participated in with the hope of being selected by the Finnish recruitment company. The number of Filipino nurses that were selected as potential for the jobs was significantly larger than the number of actual vacancies. For instance, when the hospitals recruited 25 nurses, they invited 100 best candidates from a group of 300 nurses who had taken Finnish language courses in the Philippines. A Filipino nurse who worked as a tutor employed by the recruitment company in the Philippines explained this:

When the Finns came to interview in the Philippines, it was convenient that we had already done the first selection. From 300 persons we give to [the hospital] only the 100 best. The best choices we have, of which they can choose. So it's less stress for them when they only need about twenty. 
The discrepancy between the 'pool' of potential nurses who were committed to being recruited by paying for Finnish language courses and the number of places available solidified the social construct of the Philippines as a nearly endless pool of available labour force for the Finnish health care sector. From the perspective of the Filipino nurses, the recruitment took time and there was much anticipation:

It was such a long process. We had heard a lot of promises and after a long time when we hadn't heard anything [from the company] the promises were forgotten.

When the nurses arrived in Helsinki, they lived together in furnished, rented flats segregated by gender. The rent was paid by the nurses to the hiring client. The nurses' lives became managed both in the workplace but also domestically, at least during the initial six months of their apprenticeship.

In the nursing occupation, an important hierarchical division is between practical and registered nurses. Practical nurses are like nurse aids in other countries: they have limited autonomy and authority, and often they cannot administer drugs. All the recruited nurses were registered nurses in the Philippines, and some were specialised nurses, including nurse anaesthetists or operating room nurses. Yet, regardless of their specific work experience and careers, most of the nurses were recruited for practical nursing jobs in elder care institutions. The job itself came as a shock for many interviewed nurses. An illustrative quote of what deskilling meant in practice and how nurses felt about it is the following:

I first thought that the work would be taking care of patients, but I was shocked to find out that we had to make sandwiches for them, clean their clothes, well serving food is ok, but clean their rooms and wash their clothes. 
Health care organisations are diverse, but most of the interviewed nurses are working for large, private healthcare companies. Common to the nurses' experiences is the feeling that the management is very distant from the day-to-day activities of the wards, which is common to large health care organisations. Yet, it was clear that the interviewed nurses had very little knowledge of the companies they were working for. Some of the interviewees were not even sure whether the CEO of the company had changed during their employment. With the management and HR managers being very distant, it is the ward nurses or head of the units who are the Filipino nurses' closest important bosses. It is then the relationship with the ward nurse that is crucial for the everyday working practices.

The organisational processes of being certified and, therefore recognised, as either a practical or registered nurse is controlled by the state agency, Valvira. The organisational processes of this agency are still redefining its policies regarding internationally trained nurses. However, the agency is definitive on the applications from other EU professionals. These applicants do not have to speak Finnish or Swedish, the two official languages, to practice their profession. Nor do they have to recertify their qualifications as, if their degree was obtained in the EU, the Finnish state acknowledges their education.

Conversely, the Filipino nurses must apply either on an individual basis or the recruitment agency does it on their behalf. The organisational processes of Valvira are such that the applicant, who is from outside the EU, has to have a B level (intermediate) in Finnish and must recertify themselves at an educational institution in Finland that allows them to acquire equivalent skills as the domestic nurses. As indicated by a medical counsellor at Valvira: 
We have to authorise a person that has a harmonised education inside the EU and we cannot require in that phase language skills but then the employer can enforce and has to require these language skills in order for the employee to be able to work.

These language requirements of Finnish and specific skills exclude nurses from outside the EU as it divides the nature of the work in terms of nationality and migrancy lines, in which migrants from EU are treated differently than migrants from non-EU countries. This creates different terms regarding paid work itself and renders practicing as a nurse more convenient for EU nurses than non-EU. The organisational process of Valvira also, covertly, allows for the Filipino nurses to be deskilled by enforcing institutional regulations that enable employers to evaluate the nurses' qualifications based on the organisation's needs. In this case, the private organisations employing the nurses seek to make profit by hiring practical nurses for the already existing care deficit. The Finnish employers capitalise on the local institutional mechanisms but also the GNNCs by hiring overly qualified registered nurses to work in lower paid and lower status positions, subsequently polarising the nurses based on language and nationality.

\section{Ongoing operations and inequality barriers through language}

What emerges from this research is that the construct of skills, specifically definitions of Finnish language skills, are reproduced in the recruitment practices and enforced by state regulations and yet have material consequences in the nurses' working lives in terms of contracts, pay and education recognition. The recruitment of the nurses from the Philippines was justified as the Philippines has an 'American' education system and the nurses have a high command in English. Yet, when the nurses arrive and start working in 
Finland, Finnish language emerges in the data as the foremost work requirement. In the words of a labour union representative, 'a sufficient level of Finnish language is crucial for the patients' safety':

The problem is now that we are facing, once they have gained their license here in Finland and start work as a registered nurse with their responsibilities, their language skills and their abilities, they decline. And, that is why, that's why we would like the employer (...) to be more aware of the way that they keep up with the standard and improve it because now it is not good enough. [The] patients are at risk and workmates have to do the translations, which is not a very good thing, and people are complaining about their language skills.

In the recruitment process, the nurses were trained in the Finnish language in the Philippines prior to the actual move and more language training was available postmigration on top of apprenticeship and requalifying their nursing degree. These contractual obligations made the working days longer than the domestic Finnish speaking nurses. Filipino interviewees acknowledged that acquiring language skills alongside using the language within the apprenticeship and workplace was difficult. A union representative claims:

Employers of the recruiting nurses [argue that] 'it is not our job to organise and to pay for these language training and, you know, we claim that it should be organised by the employer, it should be organised during the working hours, not at the evenings, not at the weekends because it is an important tool for a nurse to speak and write proper Finnish or Swedish.

Paradoxically, the recruiters acknowledge that the lack of Finnish language skills can partly be compensated by the Filipinos' good command of English. However, the Filipino nurses' English language skills were not recognised as an asset in the health care organisations. There was a persistent requirement on high command of Finnish. 
In the recruitment practices, Finnish language skills became an easy means to discriminate against the Filipino nurses. Consider the following experience of a Filipino nurse who has lived in Finland since the early 1990s and has completed a registered nurses' education in Finland:

I was working [in a hospital] and [the ward nurse] introduced me to the staff and said "she's a nurse", so we divided the work, and I was doing all the medicine and giving medicine to the cancer patients, and then before this ward nurse left for home, she said "I will hire you as a summer worker, but it would be as a practical nurse". The staff recognised my skills. Then when I said well I don't think I will accept the job, if I would be given a practical nurse's position, and I asked the ward manager "why practical nurse?" [She responded] "because of the language". Whereas I was talking in Finnish [to the ward nurse].

This extract demonstrates how a certain level of Finnish language skills can be used to maintain inequality in relation to recruitment and placement. Although the interviewee had Finnish credentials, a good command of the language, and uses Finnish actively in the workplace, language skills could, nevertheless, be used to justify barriers to equality in the work organisation. This is because there are no objective measures for 'good enough' command of a foreign language.

Language is then a telling example of how inequalities are done in work organisation practices, especially in recruitment, because evaluating one's linguistic skills is to some extent subjective. Foreign accent can be deemed as understandable and unacceptable and used as a ground for discrimination (Näre, 2013; Olakivi, 2013). As language competence is a legitimate reason for hiring preferences according to the law, it can be used as an excuse to discriminate against the racially and ethnically different. In the case of the direct recruitment of Filipino nurses to Finland, lacking language skills were used as a legitimation to deskill Filipino nurses from a registered to a practical nurse. 


\section{Compliant labour and barriers to equality}

Many of the recruited Filipino registered nurses, during the data collection, were placed in practical nurses' jobs. Lack of Finnish language skills were used as an excuse for the nurses' downgrading and a frequent reason why the nurses' salaries were not properly raised. The recruited Filipinos complied with the deskilling by saying that any work in Finland is better than no work in the Philippines:

It is better than not working. It is better that I come here to work as a practical nurse than stay in the Philippines as an unemployed person, ok, there is your reason from my lips.

This compliance and demand for compliance is about control, as Acker suggests, and it continued in the work itself. Although the Filipino nurses were doing the same work as their Finnish colleagues, they were treated differently in the everyday organisation and management of the work. The interviewed nurses revealed that they were given the hardest work shifts (so-called long shifts that overlapped morning and evening shift), that they were not paid for overtime but compensated by giving more days off and that sometimes their work schedule included very short shifts of less than 6 hours, which is an illegal practice in Finland.

Another Filipino nurse, who was qualified as a registered nurse and had five years of working experience in a hospital, applied to be recruited as a practical nurse in Finland because it had a better salary than what the nurse received in Philippines. The nurse indicated that as part of the training process, he studied Finnish for six months and requalified as a practical nurse. And yet, once working as a practical nurse in Finland, he 
is frustrated that due to this professional downgrading, he cannot perform certain work tasks that he would be capable of because the Finnish law forbids it from practical nurses:

I am a registered nurse in the Philippines. [In Finland] I cannot do my profession. Like, getting blood samples, I did administration, I gave medication...there is a limit on freedom because you are a practical nurse here and because also the Finnish law.

Moreover, the recruited nurses have not seen proper increases to their salaries and even though some had complained to the trade union, nothing concrete had changed in these work practices. When describing the problems in their workplaces, many of the recruited nurses were reluctant to take the issues further. The interviewees stated that they were "still learning the language" and in the process of applying for a permanent residence permit. In these circumstances, they could not risk losing their jobs. The experiences of the recruited nurses crystallize how language skills, ethnicity and vulnerability caused by their legal status as non-EU migrant workers intersect in creating barriers to equality and how the migrants have internalised these barriers themselves. Furthermore, how work requirements are redefined and skills valued or not valued intersect with assumptions regarding the Filipino ethnicity, and expectations that the Filipinos, due to their vulnerable status as migrants, remain compliant to a number of concrete barriers, which maintain and reproduce their unequal status in the health care organisations.

Ongoing transnational practices of recruiting nurses based on employers' needs and requests create GNCCs in which the nurses in the chains are allocated and organised in terms of gendered, classed and racialised assumptions. These assumptions that are interlinked within the GNCCs reinforce inequality barriers, both formally and informally, as work processes are carried out, as captured in Acker's notion of inequality regimes. 
The Filipino nurses felt that they work harder than domestic Finnish nurses but nevertheless get paid less and cannot advance in their careers because of their limited Finnish language abilities and the misrecognition of their nursing degrees from the Philippines. They also pointed out that even as their Finnish abilities improve, their colleagues still demand and expect that the Filipino nurses do the tasks that are not assigned in their job description. Designing ongoing work and managerial practices of the nurse occupation in terms of who speaks and who does not speak Finnish 'well enough' not only segregates, in terms of class and ethnic hierarchies (with very material/ tangible consequences such as wages and working hours), but also internalises compliance amongst the nurses. As mentioned by the recruited Filipino nurses, the employers and the organisational representatives, the recruited nurses comply with their workplace status and wage because of their limited abilities in Finnish. As one recruited nurse indicates, "it is like bargaining" to stay in a lower status position while improving in Finnish. The standardised hierarchies become taken-for-granted and the recruited nurses deskilled.

\section{Conclusions}

This article expands Acker's concept of inequality regimes to the literature on Global Nurse Care Chains (GNNCs) by providing an empirical study to illustrate how global power hierarchies are practiced within local organisations. Through the concept of global bases of inequality regimes, we discuss the ways in which GNCCs are created and maintained in organisation practices based on taken-for-granted global hierarchies embedded in global coloniality. 
Acker's barriers to inequality are useful to analyse the complex ways in which inequality regimes are created and maintained in organisations. We argue that to understand how inequality regimes are created and maintained in a globalised profession such as nursing, Acker's barriers need to be analysed in a global context and as embedded in global coloniality. Only by looking beyond national organisations or local recruitment and placement practices, it is possible to consider how migration legislation and regulations around educational and language requirements enhance inequality regimes. To understand the compliance of migrant nurses in accepting their unequal position, their situation needs to be understood vis-à-vis their vulnerable legal status. Thus, the migration legislation is part of the basis of the inequality regimes, as are regulations by national educational and professional authorities. Hence, while initiatives to develop ethical international recruitment such as the IRIS standard created by the International Organization for Migration (IOM) are important, they cannot fully protect migrant workers who remain dependent on their employers for continuing work contract.

A global approach to inequality regimes requires a multi-level research methodology that focuses on the experiences of individual workers and managers in national organisations, as well as other key experts in the field, including civil servants and representatives of HR companies involved in the actual recruitment. Our research is limited in that we could not conduct research in the Philippines. However, to compensate for this, our data was collected only a short time after the actual recruitment had taken place. Future research tackling inequalities in global organisations should develop multi-level but also multisited research designs that would analyse global organisations in more than one country. 
Our findings highlight that Filipino nurses are legitimately and covertly discriminated against due to their command of Finnish language and their foreign educational qualifications. Simultaneously, however, Filipino nurses' command of English language is perceived as a skill and a reason for recruitment as well as a basis on which commonality with Finnish nurses and within the Finnish health care organisations is created. Inequality regimes are by no means only imposed by the work organisations and its management practices but also internalised by the subjects affected. Hence, compliance is a crucial aspect of how inequality is done and maintained in work practices.

Our research demonstrates that GNCCs do not merely appear but are created actively through the collaboration between state authorities, corporate and municipal actors who operate transnationally. Various private and public actors interact to produce and reinforce GNCCs through on-going transnational recruitment and placement practices. This production, interlinked in the care chains, reinforces inequality regimes that transcend various levels of organising the nursing occupation. The findings suggest that tackling the global bases of inequality regimes requires addressing barriers to equality not only in specific workplace contexts but also on a national and international level including recruitment, placement, and organisational practices.

The inequality regimes organised within GNCCs are local, national, and global, involving various actors. Communicating expectations in various stages of the GNCCs, recruiters hold authority of how the Filipino nurses receive information, influencing how they perceive their work, their relationships with patients and colleagues, and the value of their work. On another level of organising, migrant nurses navigate institutional 
mechanisms to have their qualifications and education recognised as well as to continue their legal status in the country. As employers and other stakeholders in GNNCs continue to construct migrant nurses and nurse work as flexible workforces based on the needs of the managers and profitable to the stakeholders in the organisations, inequality regimes in which nursing work is undervalued as 'women's work' persists. More research is needed on global inequality regimes, but also policy responses that can account for these complex global bases of inequality regimes.

\section{Notes}

1. Nordic welfare states (Denmark, Finland, Iceland and Sweden) have developed economic and social policies based on the ideology of social egalitarianism, particularly after the World War II.

\section{References}

Acker, J. (1990), "Hierarchies, jobs, bodies: a theory of gendered organizations", Gender and Society, Vol. 4 No. 2, pp. 139-158, doi: 10.1016/j.wsif.2004.06.003.

Acker, J. (2006a), "Inequality Regimes: gender, class, and race in organizations”, Gender and Society, Vol. 20 No.4, pp. 441-464, doi: 10.1016/s0277-5395(00)00104-7.

Acker, J. (2006b), Class questions: feminist answers, Rowman and Littlefield, Lanham.

Asis, M. (2006), “The Philippines' culture of migration”, available at:

https://www.migrationpolicy.org/article/philippines-culture-migration (accessed 4 June 2020).

Cleland Silva, T. (2018), Transnational management and globalised workers: nurses beyond human resources, Routledge, New York.

Ball, R. (2004), "Divergent development, racialised rights: globalised labour markets and the trade of nurses - The case of the Philippines", Women's Studies International Forum, Vol. 27 No.2, pp. 119-133. 
Barber, P. (2000), “Agency in Philippine women's labour migration and provisional diaspora”, Women's Studies International Forum, Vol. 23 No. 4, pp. 399- 411.

Bryman, A. and Burgess, R. G. (1994), "Reflections on qualitative data analysis", Bryman, A. and Burgess, B. (Eds), Analyzing Qualitative Data, Routledge, New York, pp. 216-226.

Buchan, J., Parkin, T. and Sochalski, J. (2003), International nurse mobility: Trends and policy implications, World Health Organization, Geneva, available at: https://apps.who.int/iris/handle/10665/68061 (accessed 13 November 2020).

Carter, N. M. and Silva, C. (2010), "Women in management: Delusions of progress", Harvard Business Review, Vol. 88 No. 3, pp. 19-21.

Choy, C. (2003), Empire of Care: Nursing and Migration in Filipino American History, Duke University Press, Durham, doi: 10.1086/ahr/108.4.1173.

City of Helsinki (2019), "Ulkomaalaistaustaiset Helsingissä [People with foreign background in Helsinki]", available at: https://ulkomaalaistaustaisethelsingissa.fi/fi (accessed 11 December 2019).

Davies, C. (1995), Gender and the Professional Predicament in Nursing, Open University Press, Buckingham.

Dubois, A. and Gadde, L. E. (2002), "Systematic combining: an abductive approach to case research", Journal of Business Research, Vol. 55 No. 7, pp. 553-560.

Duffy, M. (2011), Making Care Count: A Century of Gender, Race, and Paid Care Work, Rutgers University Press, New Brunswick, NJ.

Hochschild, A. (2000), "Global care chains and emotional surplus value”, in Hutton, W. and Giddens, A. (Eds.), On the Edge: Living with Global Capitalism, Jonathan Cape, London, pp. 130-146.

Isaksen, L. W. (Ed.) (2010), Global care work: Gender and migration in Nordic societies, Nordic Academic Press, Oslo.

Kanter, R.M. (1977), Women and Men of the Corporation, Basic Books, New York.

Kingma, M. (2006), Nurses on the Move. Migration and the Global Health Care Economy, Cornell University Press, Ithaca, NY.

Lorenzo, F.M.E., Galvez-Tan, J., Icamina, K. and Javier, L. (2007), "Nurse migration from a source country perspective: Philippine country case study", Health Services Research, Vol. 42 No.3, pp. 1406-1418, doi 10.1111/j.1475-6773.2007.00716.x. 
Masselink, L. E. and Lee, S. Y. D. (2010), "Nurses, Inc.: expansion and commercialization of nursing education in the Philippines", Social Science \& Medicine, Vol. 71 No.1, pp. 166-172, doi: 10.1016/j.socscimed.2009.11.043.

Meagher, G and Szebehely, M. (Eds) (2013), Marketisation in Nordic eldercare: $a$ research report on legislation, oversight, extant and consequences, available at http://www.diva-portal.org/smash/get/diva2:667185/FULLTEXT01.pdf (accessed 15.11.2020). Stockholm: Stockholm University.

Metcalfe, B.D. and Woodhams, C. (2012), "Introduction: New Directions in Gender, Diversity and Organization Theorizing - Re-imagining Feminist Post-colonialism, Transnationalism and Geographies of Power", International Journal of Management Reviews, Vol. 14 No. 2, pp. 123-140, doi: 10.1111/j.1468-2370.2012.00336.x.

Mohanty, C. (1997), "Women workers and capitalist scripts: Ideologies of domination, common interests, and the politics of solidarity", in Alexander, MJ and Mohanty, CT. (Eds), Feminist genealogies, colonial legacies, democratic futures, Routledge, New York, pp. 3-29.

Näre, L. (2012), 'Hoivatyön glokaaleilla markkinoilla: Filippiiniläisten sairaanhoitajien rekrytointi Suomeen jälkikolonialistisena käytäntönä', [In the Glocal Markets of Care Work: The Recruitment of Filipino Nurses to Finland as a Post-colonial Practice], Sosiologia, Vol. 49 No. 3, pp. 206-221.

Näre, L. (2013), 'Ideal Workers and Suspects: Employers' Politics of Difference in the Migrant Division of Care Labour in Finland", Nordic Journal of Migration Research, Vol. 3 No. 2, pp. 72-81, doi: 10.2478/v10202-012-0017-5.

Näre, L. and Nordberg, C. (2016), "Neoliberal Postcolonialism in the Media: Constructing Filipino Nurse Subjectivities in Finland", European Journal of Cultural Studies, Vol. 19 No. 1, pp. 16-32, doi: 10.1177/1367549415585557

Organisation for Economic Co-operation and Development (OECD) (2015), International Migration Outlook, OECD, Geneva.

Olakivi, A. (2013), “In Case You Can Speak Finnish, There's No Problem”, Nordic Journal of Migration Research, Vol. 3 No.2, pp. 91-99, doi: 10.2478/v10202-012-0019-3

Parreñas, R. S. (2001), Servants of globalization: Women, migration and domestic work, Stanford University Press, California.

Philippines Statistics Authority (2019) 2019 Survey on Overseas Filipinos: A report of the overseas Filipino worker, Philippines Statistics Authority, Quezon City, available at: https://psa.gov.ph/sites/default/files/2019\%20Survey $\% 20$ on $\% 20$ Overseas $\% 20$ Filipinos.p df (accessed 23 August 2020). 
Rodriguez, R. M. (2010), Migrants for Export. How the Philippine state brokers labor to the world, University of Minnesota Press, Minneapolis.

Statistics Finland (2019) Population according to origin, background country, age and sex 1990-2017, available at:

http://pxnet2.stat.fi/PXWeb/pxweb/en/Maahanmuuttajat ja kotoutuminen/Maahanmuutt ajat ja kotoutuminen Maahanmuuttajat ja kotoutuminen/?tablelist $=$ true \& ga $=2.1043$ 26276.508436988.1576057755-1440508113.1552998421 (accessed 11 December 2019).

Tlostanova, M and Mignolo, W. (2012), Learning to Unlearn: Decolonial Perspectives from Eurasia and Americas, Ohio State University Press, Columbus.

van Riemsdijk, M. (2010), "Neoliberal reforms in elder care in Norway: Roles of the state, Norwegian employers, and Polish nurses", Geoforum, Vol.41 No. 6, pp. 930-939, doi: 10.1016/j.geoforum.2010.06.008.

World Health Organisation (2020), State of the worlds nursing 2020: Investing in education, jobs and leadership, available at:

https://www.who.int/publications/i/item/nursing-report-2020 (accessed August 20 2020).

Wrede S., Henriksson L., Høst H., Johansson S. and Dybbroe B. (Eds) (2008), Care work in crisis. Reclaiming the Nordic ethos of care, Studentlitteratur, Lund.

Vaittinen, T. (2014), "Reading global care chains as migrant trajectories: A theoretical framework for the understanding of structural change", Women's Studies International Forum, Vol 47, pp. 191-202, doi: 10.1016/j.wsif.2014.01.009.

Vartiainen, P., Koskela, M. and Pitkänen, P. (2018), Sairaanhoitajia Filippiineiltä: näkökulmia kestävään kansainväliseen rekrytointiin. Tampere University, Tampere, available at: https://trepo.tuni.fi/handle/10024/103145 (accessed June 2 2020).

Wrede, S. (2012), "Nursing: Globalization of a female-gendered profession", in Kuhlmann, E. and Annandale, E. (Eds), Palgrave Handbook of Gender and Healthcare, Palgrave Macmillan, London, pp. 471-487, doi: 10.1057/9780230290334.

Wrede, S. and Näre, L. (2013) "Glocalising care in the Nordic countries", Nordic Journal of Migration Research, Vol. 3 No 2, pp. 57-62, doi: 10.2478/v10202-012-0015-7.

Yeates, N. (2009), Globalizing Care Economies and Migration Workers. Explorations in Global Care Chains, Palgrave Macmillan, Basingstoke.

Yeates, N. (2011), "Going global: The transnationalization of care”, Development and Change, Vol 42 No 4, pp. 1109-1130, doi: 10.1111/j.1467-7660.2011.01718.x. 
Yeates, N. (2012), "Global care chains: a state-of-the-art review and future directions in care transnationalization research", Global Networks, Vol. 12 No. 2, pp. 135-154, doi: 10.1111/j.1471-0374.2012.00344.X. 
Figure 1: The key actors in the global organization of nurse recruitment from the Philippines to Finland. The perspective of those marked in italics have been included in this study.

- Valvira,

- Trade unions

- Ministry of Employment and Trade

- Nursing schools

- City of Helsinki

Finnish care companies and hospitals

\section{Finnish HR}

Service

company

- The Immigration Office

- Centre for Economic Development, Transport and the Environment

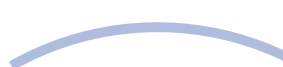

更
Philippine

Overseas Employment Administration

- Nursing schools

\section{Filipino} recruitment company

\& language training 
Table 1: The process of coding and categorising

\begin{tabular}{|c|c|c|}
\hline Line-by-line coding (Filipino nurses) & Categorising & $\begin{array}{l}\text { Larger themes related to } \\
\text { inequality barriers } \\
\text { (developed abductively) }\end{array}$ \\
\hline $\begin{array}{l}\text { Statements about personal, family and } \\
\text { educational background and work } \\
\text { experience in the Philippines, reasons for } \\
\text { migrating, prior histories of migration }\end{array}$ & $\begin{array}{l}\text { Reasons for migrating, } \\
\text { migration histories, work } \\
\text { histories, educational } \\
\text { histories }\end{array}$ & Global barriers to equality \\
\hline $\begin{array}{l}\text { Statements describing practices and } \\
\text { experiences of recruitment and placement, } \\
\text { educational and skill requirements in } \\
\text { Finland }\end{array}$ & $\begin{array}{l}\text { Recruitment in the } \\
\text { Philippines, language } \\
\text { teaching, cost of } \\
\text { recruitment, placement in } \\
\text { Finland, educational } \\
\text { requirements }\end{array}$ & $\begin{array}{l}\text { Organisational barriers to } \\
\text { equality }\end{array}$ \\
\hline $\begin{array}{l}\text { Statements describing working conditions } \\
\text { and legal status in Finland }\end{array}$ & $\begin{array}{l}\text { Conditions for labour- } \\
\text { based residence permit, } \\
\text { trade union membership, } \\
\text { knowledge of workers' } \\
\text { rights }\end{array}$ & $\begin{array}{l}\text { Barriers related to migrancy } \\
\text { and legal status }\end{array}$ \\
\hline $\begin{array}{l}\text { Statements describing experiences at work, } \\
\text { work relationship, treatment at work places }\end{array}$ & $\begin{array}{l}\text { Nursing work practices, } \\
\text { skills related to work, } \\
\text { skills related to language, } \\
\text { discrimination, cultural } \\
\text { background, ethnic } \\
\text { background }\end{array}$ & $\begin{array}{l}\text { Barriers to equality relating } \\
\text { to individual skills and } \\
\text { background }\end{array}$ \\
\hline $\begin{array}{l}\text { Line-by-line coding (recruiters and } \\
\text { representatives) }\end{array}$ & Categorising & $\begin{array}{l}\text { Larger themes related to } \\
\text { inequality developed } \\
\text { abductively }\end{array}$ \\
\hline $\begin{array}{l}\text { Statements describing reasons for labour } \\
\text { recruitment in general and nurse recruitment } \\
\text { in particular }\end{array}$ & $\begin{array}{l}\text { Perceived ideas about } \\
\text { international labour } \\
\text { recruitment and placement }\end{array}$ & $\begin{array}{l}\text { National drivers of GNCCs } \\
\text { as local basis of inequality } \\
\text { regimes }\end{array}$ \\
\hline
\end{tabular}




\begin{tabular}{|l|l|l|}
\hline $\begin{array}{l}\text { Statements describing practices of } \\
\text { recruitment and placement, the role of } \\
\text { different actors, organisational practices } \\
\text { related to recruitment }\end{array}$ & $\begin{array}{l}\text { Cross-border and local } \\
\text { management of } \\
\text { recruitment }\end{array}$ & $\begin{array}{l}\text { Organisational practices of } \\
\text { GNCCs creating inequality } \\
\text { regimes }\end{array}$ \\
\hline $\begin{array}{l}\text { Statements regarding qualities and skills } \\
\text { attributed to Filipino nurses (vs. Finnish } \\
\text { nurses), descriptions of skills }\end{array}$ & $\begin{array}{l}\text { Cultural, ethnic and } \\
\text { racialized stereotypes of } \\
\text { nurses }\end{array}$ & $\begin{array}{l}\text { Legitimation of inequality } \\
\text { regimes }\end{array}$ \\
\hline $\begin{array}{l}\text { Statements describing Finland as a country } \\
\text { of destination, statements describing the } \\
\text { Philippines as a country of recruitment }\end{array}$ & $\begin{array}{l}\text { Perceived ideas about } \\
\text { global hierarchies }\end{array}$ & $\begin{array}{l}\text { Global, ideological bases of } \\
\text { GNCCs }\end{array}$ \\
\hline
\end{tabular}

